\title{
Walter Breu* \\ Partitivity in Slavic-Romance language contact: The case of Molise Slavic in Italy
}

https://doi.org/10.1515/ling-2020-0092

\begin{abstract}
Molise Slavic is a south Slavic micro-language, spoken in three municipalities in the Italian region of Molise. It has been in a situation of total language contact with Romance varieties for about 500 years, with strong foreign influence on all linguistic levels. This paper is intended as a contribution to two combined fields of linguistics: contact linguistics and the expression of partitivity in Slavic in different settings. The paper opens with a short description of the position of the (morphological) partitive case in Russian, followed by a comparison of the role of case in expressing partitive objects in Russian, Croatian and Molise Slavic. The subsequent section will deal with other means of rendering pure and ablativic partitivity in Italian as the dominant model language and in the Molise Slavic replica, in particular with respect to the similarities and differences in existential constructions. Special attention will be paid to the Italian partitive particle ne and its formal and functional equivalents in Molise Slavic, including the particle $n a / n e$, partitive personal pronouns, quantifiers, the genitive and the role of intonation and word order. Finally we will test various hypotheses about the origin of the particle na/ne, whose formal variation in one of the Molise Slavic dialects causes serious problems for both loanword integration and semantic calquing.
\end{abstract}

Keywords: language contact, partitivity, genitive, particle, existentials, case, clitics

\section{Introduction}

Molise Slavic is spoken in three local varieties in the region of Molise in southern Italy, province of Campobasso. The ancestors of today's Molise Slavs immigrated to Italy from western Herzegovina in the Dalmatian hinterland. Their language has been under strong contact influence of the neighboring Italian varieties for about 500 years, whereas the dominance of standard Italian only dates from the

*Corresponding author: Walter Breu, Universität Konstanz, FB Linguistik, Slavistik, Fach 179, 78457 Konstanz, Germany, E-mail: walter.breu@uni-konstanz.de 
second half of the nineteenth century onwards; for more historical details see Rešetar (1911: 49-140). As Molise Slavic is a lesser-studied micro-language, practically unknown to many linguists, I consider it appropriate to give at least an outline of its sociolinguistic situation, including its demography and its areal and dialectal setting, which could be relevant for judging the role of language contact in the domain of partitivity.

Nowadays, Molise Slavic is in a situation of total (or absolute) language contact, with all its speakers being at least bilingual and with standard Italian as the umbrella language. The nearest Slavic standard language in terms of historical relationship, standard Croatian, plays no substantial role either in everyday life or, in spite of several initiatives promoting at least some form of Croatian schooling, in any form of state education; see Breu (2017: 15-16).

By now, fewer than a thousand individuals remain with at least some basic knowledge of Molise Slavic, while those actually speaking it number still fewer. Of the three Molise Slavic villages, the smallest, Montemitro, is the most conservative, with respect both to language usage and structure. In the bigger village of Acquaviva Collecroce the percentage of Molise Slavic speakers is lower, but the numbers are greater than in Montemitro; in the third village, San Felice, only a very few elderly speakers are left. Figure 1 illustrates the continually diminishing numbers of inhabitants in the three villages as a whole, using data from ISTAT, the Italian National Institute of Statistics, combined with my own estimations about the degree of active and passive language conservation.

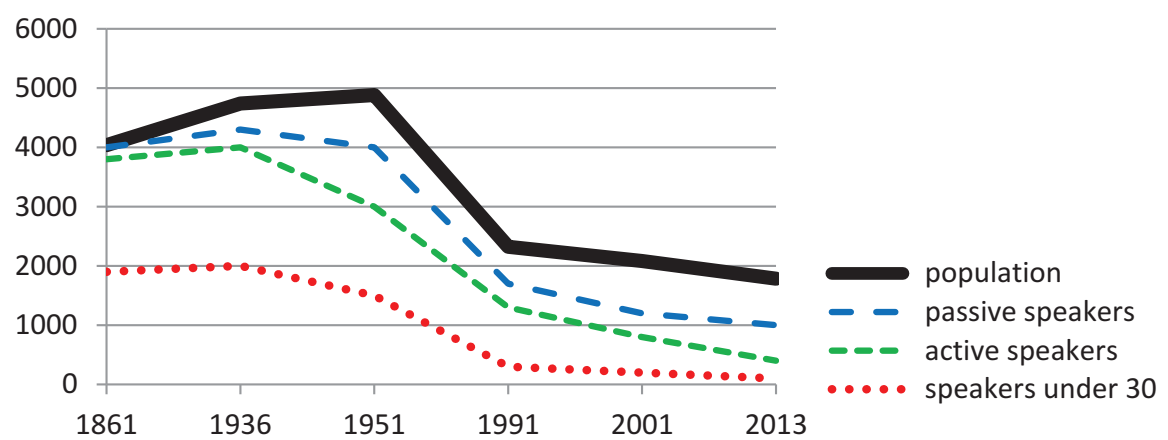

Figure 1: Inhabitants and speakers in the Molise Slavic municipalities.

The peak of the demographic development was in 1951, when the population reached an overall total of almost 5000 inhabitants, while in 2013 fewer than 2000 people were left, only half of them being able to understand the minority 
language. Active speakers under 30 are very rare by now, and there is a clear tendency towards language death in the next decades.

There are linguistic differences between the dialects of these villages on all linguistic levels. The most important for our research in partitivity is phonetic, namely the pronunciation of unstressed $e, o$ as a schwa-like centralized $a$, due to Molise Slavic akanye, typical for Acquaviva and San Felice but absent in Montemitro. For example, vino 'wine' in Montemitro sounds like vina in the other two villages, and grozdje 'grapes' has become grozja in Acquaviva and ghrozdja in San Felice.

As for morphology, a salient difference resides in the dative singular of feminine nouns, with three different case endings, $-u$ in Acquaviva, $\varnothing$ in Montemitro and $-i$ in San Felice. Historically $-i$ is the base form, which got lost in Montemitro, whereas it was replaced by the accusative ending in Acquaviva. There are also considerable differences in the development of the ancient locative, especially in the feminines, resulting in a very complex system in Montemitro, while the two other dialects simply replaced it by the accusative. ${ }^{1}$ With respect to syntax, the Molise Slavic dialects are rather homogeneous. On the other hand, the lexicon is quite varied, even with respect to basic terms of agriculture like the word for 'field', with the genuine-Slavic njiva in Acquaviva, the loanword largo in Montemitro and in San Felice the borrowed pajiz.

Language contact is decisive for the development of Molise Slavic. Our most important innovation here is the theoretical concept of diagrammar, which assumes that bilinguals, in principle, have a common grammatical system for both languages in contact. ${ }^{2}$ Language-specific rules based on this diagrammar are responsible for differences still not levelled out. The ideal case, which could be regarded as the overall motivation of contact-induced change, is a comprehensive diasystem with a common semantic structure, without any languagespecific rules. It would allow bilingual speakers to pass easily from one language to the other, by simply re-lexicalizing this common grammar with the words needed in the language they are actually speaking in a given moment.

1 For a short overview of the Molise Slavic grammar, including dialectal differences between the three Molise Slavic dialects and the question of contact-induced change and lexical borrowing, see Breu (2017: 16-72). The feminine declension is addressed on pages 31-34.

2 The concept of diagrammar (grammatical diasystem) is the grammatical equivalent to the concept of a compound sign "with a single signified and two signifiers", put forward by Weinreich (1979 [1953]: 9) with respect to the interpretation of lexical entities by bilinguals. The term “diasystem” itself goes back to Weinreich (1954: 390): “A 'diasystem' can be constructed by the linguistic analyst out of any two systems which have partial similarities ... But this does not mean that it is always a scientist's construction only: a 'diasystem' is experienced in a very real way by bilingual (including 'bidialectal') speakers ...”. 
The development of such a diagrammar in Molise started centuries ago, more or less immediately after the immigration of groups of Slavic speakers, who adapted the semantic structure of their south Slavic variety to that of the language of their Romance-speaking neighbors. ${ }^{3}$ But it is still only a strong tendency that has not yet been fully completed, in the sense that certain language-specific differences between Molise Slavic and the Italian varieties continue to exist. Some grammatical phenomena seem to be particularly resistant to adaptation, normally of the replica languages to the dominant model language, especially when inflection and clitics are concerned as means of expressing certain grammatical concepts. Partitivity could be such a concept, the more so as traditional Slavic ways of expressing it are formally rather different to Italian. Suffice it to mention the fact that in many Slavic languages genitive case forms of nouns and pronouns are the most prominent means of expressing partitive meaning, whereas in Italian, a language without morphological case in the nominal system, the most typical way of expressing partitivity is by means of a clitic particle, known as ne in its standard Italian form. In the Italian nominal system, it is prepositional phrases with $d i$ 'of', preceding mass nouns and the plurals of count nouns, that can have partitive function.

In this paper, partitivity is considered as just one case out of a set of subdivisions of an entity in the case of mass nouns or a number of entities in the case of count nouns. They are connected semantically by the concept "part of". The single constituents of this set could be ordered provisionally as follows, with only cursory efforts made to fit functional descriptions: negative existential (no parts) < existential (at least one, some) < indefinite (one/part of many/ much) < partitive (some parts) < quantity (several, few, many parts).

After a short description in the following paragraph of the functions of the partitive $^{4}$ case and the genitive in object position in Russian and Croatian,

3 Besides matter borrowing of loanwords, the adaptation of the semantic structure is the most prominent process in levelling out differences between languages in contact in the lexicon as well as in grammar. It is typically based on existing polysemies in the dominant language that are copied in the replica languages. Here are two examples. The first concerns the lexicon: in Italian paese means both 'country' and 'village', two meanings that in Slavic languages are expressed by different words. As a result of the adaptation of the semantic structure, the Italian polysemy is conferred to Molise Slavic, where the word grad, originally restricted to 'village', now also means 'country'. In grammar, this type of semantic calquing led, for example, to a meaning extension of the bi-conditional to a future in the past, with ona bi dola 'she would come' also referring now to a future event embedded in a past-tense situation. This goes back to the model of Italian varieties with a similar polysemy of its conditional; for more details of the adaptation of the semantic structure see Breu (2003).

4 Terminology in the domain of partitivity is by no means homogeneous, neither for the forms expressing it nor in functional respects. For example, the term "partitive" is used both for 
compared with the sharply differing system of Molise Slavic, we will discuss also other means for expressing partitivity in the Slavic-Romance situation of total language contact, especially partitive particles and pronouns. Molise Slavic data will be compared with their Italian equivalents, in order to determine parallels and possible complications for the diagrammar of bilingual speakers. Based on these results, we will discuss the probability of contact-induced change in the field of partitivity in this minority language.

The examples discussed in this paper have been chosen to give an overall picture of the morphological and syntactic means for expressing partitivity. As a consequence, in some cases they are more important for the description of the system of this micro-language itself than they may be for the further development of some theoretical hypotheses on partitivity. On the other hand this approach allows for a fine-grained overview of the single means of expression in the domain of partitivity and their interaction in Molise Slavic as a whole and in its dialectal variants, but also with respect to the possible influences of the dominant Romance varieties as a model for diachronic change in this micro-language.

\section{The opposition between partitive, genitive and accusative in Slavic}

In order to show the position of Molise Slavic and its way of expressing partitivity within the Slavic language family, two other Slavic languages will be discussed as points of comparison. The first is Russian with its very special system of a morphological partitive case, most probably the result of language contact, and the interaction of partitivity with verbal aspect. The second is standard Croatian,

functions and the forms expressing them, from morphological cases down to analytic constructions of several types. On the other hand, for example, Daniel (2014) and Paykin (2014) avoid the term "partitive" for the Russian case in question by using the denomination GEN2 or "second genitive" instead, and restrict "partitive" to the partitive function of the genitive. Koptjevskaja-Tamm (2001) and de Hoop (2003) apply the term "partitive" to the function of a part taken from a whole, in examples like a piece of the cake, while renaming the traditional partitive type in examples like a cup of tea, being the basis for terms like "partitive genitive", as "pseudo-partitive". In this paper we will use small capitals for the partitive case, in order to avoid confusion with partitive functions expressed by other linguistic means in the functionalsemantic field of partitivity. The same method is used also for the other (morphological) cases, especially the locative, in order to differentiate it from functional denominations referring to place, as in "locative particle". As for functions, we will differentiate between several subtypes by using the terms "bare (independent) partitive" (some tea), "quantified (bounded) partitive" ( a cup of tea), and "ablativic partitive" (a piece of the cake). 
"genetically" (phylum) much nearer to Molise Slavic but, as it seems, without foreign influences in the field of partitivity. In spite of their rather different ways of expressing partitivity there is a common denominator for Croatian and Russian in the important (but different) role of their genitive. It will be interesting to see how Molise Slavic has formed a third, clearly different way, and to analyze what role language contact could have played in this development.

Slavic case systems, in general, do not contain a special partitive case, with the only exception being the so-called "second genitive" in Russian. It exists only in masculine nouns, where its ending $-u$ is in contrast with the $-a$ of the genitive, for example, narodu PAR.SG.M: naroda GEN.SG.M (other examples below). Only a limited set of masculines form such a partitive. Note that in spite of mainly expressing partitivity, this case has some additional functions, too, again strongly limited both with respect to the type of constructions involving it and their stylistic range of usage. ${ }^{5}$ On the other hand the Russian partitive may always be substituted with a regular genitive form (although the partitive is often the preferred variant), while the opposite is not true (Daniel 2014). So, its position in the Russian declensional system is rather marginal, still more marginal than the new locative, another special case form restricted to Russian. ${ }^{6}$

Both innovative case formations, the partitive and the locative, seem to be a product of language contact in medieval Russian, most probably due to the Finnic substrate languages ${ }^{7}$ existing in territories later populated by Slavic tribes. Some evidence for such a special development in Russian lands is provided by the fact that it is, indeed, restricted to these areas and that Finnic case systems show a

5 There are, for example, fossilized prepositional phrases with the partitive of the type iz domu 'out of the house' instead of the genitive variant $i z$ doma or so straxu 'in fear' instead of so straxa. For more details see Daniel (2014) and, for Russian dialects, Seržant (2014).

6 The Russian locative is an innovation with respect to Proto-Slavic. It forms an opposition with the traditional prepositive case, in the same way as the partitive does with the genitive. In other Slavic languages, which do not differentiate between these two cases, locative is the term for what in Russian is the prepositive. A Russian masculine example is $v$ sadu LOC 'in the garden' vs. $o$ sade PREP 'about the garden', with the different case endings being accompanied by different positions of stress (word final stress in the locative). Unlike the partitive, the locative is never optional. Another type is found in feminines of the $i$-class, in which final stress alone differentiates the locative from the prepositive, e.g., $v$ svjazi LOC 'in connection' vs. o svjazi PREP 'about the connection'. There has been a long discussion about the status of both locative and partitive in the Russian case system, ranging from secondary case over subcase to independent case; see, for example, Daniel (2014: 348, 371).

7 Substrate situations of language contact have to be strongly differentiated from adstrate situations like that of Molise Slavic in contact with Italian. For the different directions of language contact see, for example, Breu (1994: 45-48) and van Coetsem (2000). In the first case L1 influences L2, with the result of an L2', containing many elements of L1, inserted there 
partitive and several locative cases (Luraghi and Kittilä 2014), which L1-speakers could have transferred to their Slavic interlanguage (Breu 1994: 51). Of course, this hypothesis requires the existence of endings in older Russian that could be reinterpreted. And in fact, forms of this kind did exist in historical Slavic, namely in the ancient masculine $u$-declension, which was increasingly replaced by the dominant $o$-declension, with its endings - not only its genitive and locative endings but also, for example, its dative - eventually becoming free variants of the corresponding case endings of the latter. ${ }^{8}$ In many Slavic languages, this new variation led to innovations in different grammatical categories, for example, animacy $(o$-declension $=>$ animate, $u$-declension $\Rightarrow>$ inanimate), the rise of special case forms (coming from the $u$-declension) for velar stems or the strengthening of the gender opposition between masculine ( $u$-declension) and neuter (o-declension), and, as observed in the case of Russian, new case oppositions. Table 1 gives a short overview of this reorganization in some north Slavic languages; for more information see Breu (1994: 48-52).

Table 1: Endings of the Proto-Slavic $u$-declension in modern standard languages.

\begin{tabular}{lllll}
\hline${ }^{*} \boldsymbol{u}$-declension & Russian & Polish & Czech & Upper Sorbian \\
\hline GEN.SG $-\boldsymbol{u}$ & PARTITIVE & - animate & - animate & $(-)$ \\
LOC.SG $-\boldsymbol{u}$ & LOCATIVE & velar declension & velar declension & velar declension \\
DAT.SG - ovi & - & + personal & + animate & $\mathrm{M} \neq \mathrm{N}$ \\
\hline
\end{tabular}

In several Slavic languages, there is an opposition between the accusative, expressing an object as an integral whole, and the genitive, referring to only a certain quantity of the object. This is the case in the Russian examples (1a) and

as a consequence of the conservative behavior of L1-speakers or rather imperfect learning (inertia), which becomes fossilized when L2' speakers abandon their original L1. In adstrate (or superstrate) situations L1 speakers conversely integrate elements of the foreign L2 into their own L1, which in this way is (actively) transformed into $\mathrm{L1}^{\prime}$. In adstrate situations lexical borrowing is the main process of contact-induced change, whereas in substrate situations mainly grammar is concerned. But in both cases the opposite levels can also be affected, either by conserving lexical entities of L1 (substrate) or by grammatical change in a long-lasting contact situation, mainly by means of the adaptation of the semantic structure (adstrate), as was the case in Molise Slavic.

8 In other words this obsolete morphological material of the former $u$-declension became free for expressing other categories or, as Luraghi and Kittilä (2014: 51) put it with regard to the newly formed Russian partitive: "The $-u$ stem genitive, which had lost its function following the disappearance of the inflectional class to which it belonged, was so to speak re-cycled, and acquired a new function, for which there was previously no dedicated morpheme.” 
(1b). A side-effect of this constellation is a certain affinity of the accusative to definiteness in objects of perfective verbs, where partitivity is expressed by means of the genitive. In nouns having a special form for the partitive, the genitive may optionally be replaced by the latter; see (1c).
a. Ona vypila
vodu
she drink:PFV.PTCP.SG.F water:ACC.SG.F
'She drank (all) the water.'
b. Ona vypila vody.
she drink:PFV.PTCP.SG.F water:GEN.SG.F
'She drank (some) water.'
c. Ona vypila
čaju.
she drink:PFV.PTCP.SG.F tea:PAR.SG.M
'She drank (some) tea.'

( čaja GEN : čaj ACC)

Interestingly, this opposition interacts with verbal aspect (Paykin 2014). While for the opposition in (1) the perfective verb vypit' 'to drink' is used, allowing for both an accusative and a genitive/partitive object, the corresponding imperfective verb pit' 'to be drinking' in affirmative, not habitual examples, normally combines only with an accusative object. ${ }^{9}$ So, only a sentence like (2a), formally corresponding to the perfective example (1a), but with the partitive meaning of $(1 b) /(1 c)$, would in fact be possible, whereas (2b) with a combination of the imperfective verb with the genitive or partitive is excluded (ungrammatical).
a. Ona pila
vodu.
(̌̌aj ACC)
she drink:IPFV.PTCP.SG.F water:ACC.SG.F
'She drank (some) water.'
b. Ona pila $\quad{ }^{*}$ vody.
she drink:PFV.PTCP.SG.F water:GEN.SG.F
$\left({ }^{\star} \check{c} a j u,{ }^{*} \check{c} a j a\right)$

\footnotetext{
9 We are speaking here about the process function of the imperfective aspect, referring to episodic states of affairs. There are some exceptions from the exclusion of the partitive and the partitive genitive from imperfective aspect, for example when the wider context embeds the imperfective verb in a sequence of events, which Paykin (2014: 395) calls "a special set-up of a spatio-temporal situation" sufficient for a delimitation. It seems, however, that such cases are restricted to the historical present, where the imperfective aspect replaces the perfective aspect only formally without any additional meaning.
} 
Besides case and aspect, negation also has a role in the whole/part opposition. In this domain the genitive/partitive is preferred to the accusative for mass nouns and the plural of count nouns, even with the imperfective aspect as in (3). ${ }^{10}$
Ona ne pila
vody.
(čaju PAR, čaja GEN)
she not drink:PFV.PTCP.SG.F water:GEN.SG.F

Croatian, the Slavic standard language that is "genetically" nearest to Molise Slavic, differs from Russian in using its genitive with a partitive function also in affirmative sentences, independent of the verbal aspect of the verb; see (4a) for the imperfective verb piti 'to drink' and (4b) for its perfective counterpart popiti. On the other hand, the accusative expresses the object as an integral whole, normally with a connotation of definiteness, again with the verbs of both aspects (4c). Negation allows for the genitive also in the case of definiteness, but such a usage of the so-called "Slavic genitive" is restricted to a rather formal code (4d). ${ }^{11}$ There is no special partitive case in Croatian, but there are verbs with a special partitive meaning, for example napiti se 'to drink enough of', governing the genitive instead of the direct object in the accusative.
a. Pila
je
vode.
drink:IPFV.PTCP.SG.F AUX.3SG water:GEN.SG.F
'She was drinking (some) water.'
b. Popila je vode.
drink:PFV.PTCP.SG.F AUX.3SG water:GEN.SG.F
'She drank (some) water.'
c. Pila/popila je vodu.
drink:IPFV/PFV.PTCP.SG.F AUX.3SG water:ACC.SG.F
'She was drinking/drank the water.'

\begin{abstract}
10 Though genuine examples are rare, some native speakers accept the combination of the imperfective verb pit' 'to drink' with a partitive or genitive object in the case of iteration or habituality; with an explicitly habitual imperfective like vypivat' 'to drink usually' as in ja prixodil i vypival čaju/čaja s ženoj 'I used to come (IPFV) and to drink (IPFV) tea (PAR/GEN) with my wife', all informants accepted the PAR or the GEN object. This is due to the fact that in such cases the imperfective aspect does not express a process but the repetition of a complete event, requiring the perfective aspect in non-iterated situations. Though the PAR object is generally preferred in such cases, this does not really contradict the claim that replacing the partitive by the genitive is always possible, put forward, for example, in Daniel (2014).

11 For some details of the usage of the genitive in a partitive function in Croatian see Raguž (1997: 121-122). The term "Slavic genitive" refers to its probably Old-Church-Slavonic origin, responsible also for its stylistic peculiarities.
\end{abstract}


d. Nije pila/popila vodu/vode.

NEG.AUX.3SG drink:IPFV/PFV.PTCP.SG.F water:ACC/GEN.SG.F

'She was not drinking/drank (some, the) water.'

Existential constructions, using imati 'to have' in the present (5a) and the neuter participle of biti 'to be' in the past (5b), also require the genitive. ${ }^{12}$ As indicated in brackets, this holds true for their negation, too.

a. Ima

vode.

(nema 'there is no')

have:PRS.3SG water:GEN.SG.F

'There is water.'

b. Bilo je vode.

(nije bilo 'there was no')

be:PTCP.SG.N AUX.3SG water:GEN.SG.F

'There was water.'

As for Molise Slavic, the situation is again different. In the first place, as in Croatian but unlike in Russian, aspect has no role for the expression of partitivity. On the other hand, unlike in both standard languages, there is no partitive genitive at all for nouns in object position; see Examples (6a)-(6b). ${ }^{13}$ Note that this is also true for sa napit 'to drink', the perfective counterpart of pit', ${ }^{14}$ which formally corresponds to the Croatian verb napiti se 'to drink enough', governing the genitive. As shown by the sentence-initial position of the clitic auxiliary je in the examples in (6a)-(6b), compared with those in (4a)-(4c), Molise Slavic has adopted the Italian word order that places clitics before (and after) the main verb, irrespective of the position of the latter in the sentence. ${ }^{15}$ By contrast, Croatian retains the original Slavic word order with clitics generally following

12 Contrary to this impersonal usage of imati/biti with the genitive in existential constructions, imati governs the accusative in affirmative personal constructions like ima vodu 's/he has water', whereas biti goes with nominative predicates as in voda (NOM.SG.F) je bila dobra 'The water was good'.

13 Examples in this paper were discussed with competent speakers. For Molise Slavic my thanks go to the local informants, especially to Nicola Gliosca and Giovanni Piccoli. I am also grateful to Malinka Pila for discussing the Italian examples. Any mistakes or misunderstandings are, of course, my own.

14 On the whole, the formation of a reflexive perfective from a non-reflexive imperfective is rather exceptional for Molise Slavic, as it is for the Slavic languages overall, the more so as sa napit is also special in governing the accusative in spite of being reflexive.

15 Actually, what was copied from Italian was the position of the entire clitic block, while the internal order of the single clitics remained different, as we will see below in combinations of the auxiliary je with clitic pronouns. For more details on the word order of clitics in Molise Slavic see Breu (2019: 417-420). 
the first fully stressed word in the sentence. As shown by Example (6c), negation does not influence the way partitivity is expressed in the noun, again contrary to Croatian. This means that the object is exclusively in the accusative, as in the affirmative statements.

a. Je

pila

vodu.

( ${ }^{\star}$ ode GEN)

AUX.3SG drink:IPFV.PTCP.SG.F water:ACC.SG.F

'She was drinking (some/the) water.'

b. Je sa napila vodu.

( ${ }^{\star}$ vode GEN)

AUX.3SG REFL drink:PFV.PTCP.SG.F water:ACC.SG.F

'She drank (some/the) water.'

c. Nije pila/sa napila

vodu.

$\left({ }^{\star}\right.$ vode GEN)

NEG.AUX.3SG drink:IPFV/PFV.PTCP.SG.F water:ACC.SG.F

'She was not drinking/did not drink (some, the) water.'

Summing up some of the results of these comparisons, Table 2 gives an overview of the interacting means of expression for partitivity in nouns with respect to case, aspect and negation.

Table 2: Grammatical interaction of case, aspect and negation in the domain of partitivity.

\begin{tabular}{lccc}
\hline & Russian & Croatian & Molise Slavic \\
\hline PARTITIVE case & + & - & - \\
IPFV/PFV + ACC & + & + & + \\
PFV + GEN/PAR & + & + & - \\
IPFV + GEN/PAR & - & + & - \\
Partitivity by case & PFV + , IPFV - & + & - \\
GEN of negation & + & $(+)$ & - \\
\hline
\end{tabular}

As the table shows, only Russian has an independent partitive, and in all three languages direct objects are found in the accusative (of both aspects). The (partitive) genitive and the partitive combine with the perfective aspect in Russian and Croatian, whereas in Russian their combinations with the imperfective aspect (when referring to affirmative, non-iterative situations) are excluded. As a consequence, the expression of partitivity by means of case oppositions is possible in both aspects in Croatian, but (with certain exceptions) restricted to the perfective aspect in Russian and excluded in Molise Slavic. The genitive of negation is possible in Russian and Croatian. It is not obligatory in Russian, but certainly more frequent than in Croatian. Obviously, Molise Slavic 
clearly differs from the other two Slavic languages in not using case for the expression of (bare) partitivity at all. In the following, we will show other means of expression for partitivity in Molise Slavic and compare them with Italian, in order to discuss the possible role of language contact in this field.

\section{The role of language contact in Molise Slavic partitive constructions}

\subsection{Comparing the expression of partitivity in Italian and Molise Slavic}

As Italian has no nominal case system, Italian influence on the usage of case in Molise Slavic for expressing partitivity in nouns is very limited. The only effect of language contact on that score might be seen in the very absence of case oppositions as a method for differentiating partitivity from an ordinary (accusative) object, dealt with in paragraph 2. However, other examples show clearly that Italian has, indeed, had its role in the field of partitivity constructions in Molise Slavic.

Standard Italian partitive constructions with nouns in object position are formed by means of the preposition $d i$ 'of' amalgamated with the definite article to forms like del, dei, dell', while, roughly speaking, the omission of this preposition expresses definiteness and the additional omission of the article leads to a generic meaning. See Example (7) for mass nouns and the plural of count nouns, with di-partitives to the left, definite objects in the center and generic statements to the right.

(7) a. Ho bevuto dell'acqua. : Ho bevuto l'acqua. : Ho bevuto acqua.

'I drank some water.' : 'I drank the water.' : 'I drank water.'

b. Ho comprato dei libri. : Ho comprato i libri. : Ho comprato libri.

'I bought some books.': 'I bought the books.': 'I bought books.'

Molise Slavic does not have differentiations of this kind. Here a sentence like sa pija vodu (ACC.SG.F) has all three meanings of (7a), and sa kupija libra (ACC.PL) has all three meanings of (7b). In this micro-language the most frequent way of expressing partitivity with nouns is by adding quantifiers, whose original quantitative meaning is weakened, in particular na mala 'a little, some' for mass nouns, an adverbial, governing the genitive as in (8a). For the plural of count nouns nike, the plural of the indefinite article, and $d v a \mathrm{M}, d v i \mathrm{~F}$ 'two' (losing its original function as a precise number) are used. See (8) for some original 
examples from recorded oral texts. As shown by Example (8b) with the noun of the partitive construction in the nominative, the expression of partitivity by means of (weakened) quantifiers is not restricted to direct objects.

a. $B i$

bila

dobra jizist

na

mala

COND.3SG be:PTCP.SG.N good eat:PFV.INF ART.INDF little cukra.

sugar:GEN.SG

'It would be good to eat some sugar.'

b. $\mathrm{Su}$ dol nike čeljade doma naša.

AUX come:PTCP.PL ART.INDF.PL person:NOM.PL.M home our.

'Some people came into our house.'
c. $S a$ poša nabra dva boba. ${ }^{16}$
AUX go:PTCP.SG.M harvest:PFV.INF two.M broad.bean:GEN.SG.M
'I went to harvest some broad beans.'

d. Što čuvaš te $e^{17}$ dvi ovce?

why herd:PRS.2SG these two:F sheep:ACC.PL.F

'Why are you herding these few sheep?'

It is worth noting that these possibilities for rendering partitivity in Molise Slavic have direct counterparts in the local southern Italian varieties (and beyond), with na mala corresponding to un po' di 'a little of, some' combined with mass nouns and $d u(e)$ 'two, some' used with count nouns (Rohlfs 1968: 119). Even the plural of the indefinite article has a counterpart in the form of certi 'certain', ${ }^{18}$ frequently used by local Italians as well as by bilingual Molise Slavs. On the other hand, partitive constructions like those in the left row of (7a)-(7b) are absent in southern Italy (Rohlfs 1968: 118). At least in the case of the numeral 'two', the partitive function is undeniably induced by language contact, as no

16 The numeral 'two' governs the paucal, which is identical to the genitive singular for masculine nouns, whereas feminine nouns and adjectives of all genders combine with plural forms (Breu 2013: 12-16).

17 As this example shows, partitivity does not exclude definiteness.

18 Just like Italian certi 'certain', the Molise Slavic indefinite plural article nike seems to have a connotation outside bare partitivity, in the sense of an implicit judgement (normally: 'strange') on the things or persons in question. As for the indefinite article jena itself, which was induced by language contact (see below), it also has a morphologically regular plural jene; this, however, only combines with pluralia tantum in their singular reading and with the same connotation as nike. With count nouns, generally, only nike is possible. As an (only marginally partitive) exception we found a single example in the Molise Slavic text collections with jene attributing a plural noun, Ma jene žene, ma ue!, rendered in Italian as Ma certe donne, eh! 'But (they were) certain (=strange) women, ha!' (Breu and Piccoli 2012: 171). 
other Slavic language has it. But also in the other cases the exactly parallel usage of the local Italian and Molise Slavic constructions speaks in favor of foreign influence.

\subsection{Existential constructions in Italian and Molise Slavic}

Unlike the independent genitive of nouns, excluded as a marker of partitivity in Molise Slavic, clitic genitive pronouns can overtly express it in many cases. Partitive existential constructions are one such case. ${ }^{19}$

In Italian, (bare) existentials are formed by adding the locative particle $c i$ (becoming ce before other clitics, $c$ ' before vowels) ${ }^{20}$ to the existential verb essere 'to be'. In Molise Slavic there is no such particle. Existentiality is therefore expressed by the verb bit 'to be' alone; see Examples (9a)-(9b) with original sentences, translated by bilingual speakers into Italian. Note again that the noun relating to the referent, whose existence is in question, is always in the nominative, not in the genitive, unlike, for example, in Croatian. This holds true even in negative contexts like (9b).

a. Cici,

je

voda

tota?

uncle:VOC.SG.M be:PRS.3SG water:NOM.SG.F here

Italian: Zio, c'è l'acqua qui ? $^{21}$

'Uncle, is there water here?'

19 This is not the place to enter into the discussion about the general structure of existentials. For a typological view and a discussion of recent theories in this field see the Italian Journal of Linguistics' special issue about existentials 25.1, especially Bentley et al. (2013: 1-13).

20 We call Italian ci (ce, c') a locative particle for etymological reasons, as it developed from the Latin locative adverb ecce-hic 'right here'; see Rohlfs (1969: 168-169). But this term is also synchronically motivated. Just like English there, it still has locative (including directional) functions outside the existentials, e. g., qui ci abito da un pezzo 'I have been living here for some time', ci vieni anche tu? 'will you also come there?'. Locative $c i$ is homophonous with the dative plural of the personal pronoun noi 'we' from Latin hinc 'here'. On the other hand, the Italian partitive particle ne (see below), going back to Latin inde (Rohlfs 1968: 465), has a locative etymology, too.

21 Bilingual Molise Slavs prefer the definite article in Italian even where omitting the article would be perfectly possible or even preferred by monolingual Italians to avoid an anaphoric reading. Such a case is the generic usage of the definite article with mass nouns in a sentence like (9a), where a translation c'è acqua qui? without the article would also be possible. This is a secondary effect of the development of a contact-induced article system in their language as a result of copying the polysemy of Italian uno, functioning as both the numeral 'one' and as an indefinite article, with the result of their numeral (je)na becoming also an indefinite article (adaptation of the semantic structure); see Breu (2012, 2019: 411-414). As the usage of the 
b. Nonda voda ne biša doma.

then water:NOM.SG.F NEG be:IPRF.3SG at.home

Italian: Allora non c'era l'acqua in casa. ${ }^{22}$

'Back then, there was no water in the house.'

The genitive is used, however, when quantity is expressed explicitly. In such cases, as for example in (10), with the quantifier čuda 'much, many', the Italian equivalent is just an ordinary noun in its base form. This is due to different properties of this quantifier in the two languages. In Molise Slavic čuda is an adverb, governing the genitive, whereas Italian molto behaves like an attributive adjective, agreeing with the noun in number and gender. See (10a) for an affirmative and (10b) for a negative example. The antonym na mala 'little, few', mentioned above in Example (8a), actually has an exact parallel structure in Italian, namely un po' $d i$, with the preposition $d i$ 'of' corresponding to the genitive in Molise Slavic.
a. $M a$ je
čuda hjena.
but be:PRS.3SG much hay:GEN.SG.M
Italian: Ma c'è molto fieno.
'But there is much hay.'
b. Ne biša čuda vode.
NEG be:IPRF.3SG much water:GEN.SG.F
Italian: Non c'era molta acqua.
'There was not much water.'

In Italian bare existentials are transformed into partitive existentials by adding the partitive particle ne ( $n$ ' before vowels), referring to mass nouns and to count nouns in the plural. In Molise Slavic its equivalents are personal pronouns in the genitive, agreeing in number with the nouns they refer to (the pivot of the existential). Compare, for example, the bare existential (11a) with (11b). According to the order of clitics in Molise Slavic, the genitive pronoun ( $\mathrm{g} a \mathrm{M}$, $j e \mathrm{~F}, h i \mathrm{PL}$ ) precedes the existential verb in the same way as the partitive particle

indefinite article is obligatory in all cases in which it is used in Italian, the lack of the indefinite article is identified with definiteness, hence with the Italian definite article. In anaphoric usage this does not create any problems, and even in generic function Italian often uses the definite article. But sometimes this identification of the absence of the indefinite article with the definite article leads to an overgeneralization.

22 Again, an Italian translation acqua without the definite article would also be possible in (9b). But according to native speakers the reference to water supply, meant here, is clearer with the article. 
does in Italian. This means that we have a double parallel in the diagrammar of the bilingual speakers, the partitive markers themselves and their position. As is shown in (11c)-(11d), the same is true for questions.

(a) Je sir. (b) Sir ga je. (c) Je sir? (d) Ga je sir?

Italian: (a) C'è formaggio. (b) Formaggio ce n'è. (c) C'è formaggio?

(d) Ce n'è formaggio?

(a) 'There is cheese.' (b) 'There is some cheese.' (c). 'Is there cheese?'

(d) 'Is there some cheese?'

In negative existentials like (12) the situation is more complicated, as the clitic pronoun already accompanies the negated existential verb itself, to which it is postponed (marked by a hyphen). Consequently, a second copy of the clitic pronoun precedes the verb when partitivity is involved as in (12b), (12d).

(12) (a) Sir nije-ga. ${ }^{23}$ (b) Sir ga nije-ga. (c) Nije-ga sir? (d) Ga nije-ga sir?

(a) Il formaggio non c'è. (b) Il formaggio non ce n'è. (c) Non c'è formaggio?

(d) Non ce n'è formaggio?

(a) 'There is no cheese.' (b) 'There is not any cheese.' (c) 'Is there no cheese?'

(d) 'Isn't there any cheese?'

Examples of partitive existentials with additional quantifiers are provided by (13a) with the masculine mass noun sir 'cheese' and (13b) with the plural of the count noun tartuf 'truffle', with the preceding clitic genitive pronouns ga and $h i$ corresponding to Italian ne. In the given sentences, partitivity is also expressed on the noun itself, by means of the preposition do 'of, from', governing the genitive. This prepositional phrase can also be omitted, if the referent in question is clear from the wider context. If it is present, the whole construction can be interpreted as an "ablativic (existential) partitive". ${ }^{24}$
a. Do sira
ga je
čuda.
of cheese:GEN.SG.M he:GEN be:PRS.3SG much
Italian: Di formaggio ce n'è molto.
'Of cheese, there is much [of it].'

\footnotetext{
23 In the plural, negative existentials have the verb in the singular; for example: Nija (be:NEG. PRS.3SG) hi (they.PL) čeljade (person:NOM.PL) nama-dol 'there are no persons down there'.

24 As defined above, this is the type of a piece of the cake, interpreted as ablativic "taken from the cake", different from the "bounded partitive" of the type a cup of tea and the "bare partitive" in some tea, but, of course, extended by means of the quantifier.
} 

b. Do tartufi
sa
hi
naša
tri.
of truffle:GEN.PL AUX.1SG they:GEN find:PTCP.SG.M three.
Italian: Di tartufi ne ho trovati tre.
'Of truffles, I found three [of them].'

The obvious model for the prepositional phrase with do is the corresponding Italian construction with the preposition di. When Molise Slavic do is omitted, the bare noun may appear in the nominative, in spite of the (bare) partitive function it has in such cases. This is the normal case when the quantifier čuda 'much' is not present, as in the bare existential in the abovementioned example (11a) Je sir (NOM.SG.M) 'There is cheese' and in the corresponding partitive existential (11b). When it is present, the prepositionless genitive may prevail, but in this case governed by the quantifier, resulting in (13a') Sira (GEN.SG.M) je čuda 'There is much cheese' (quantified partitive). The ungoverned nominative is possible in this case, too, but with the clitic genitive pronoun being placed immediately before the quantifier: (13a") Sir (NOM.SG.M) je ga čuda. ${ }^{25}$

Ablativic partitives may be found outside the existentials, too, for example in (14a). Here it is again possible to omit the preposition do, with the genitive government passing over to the quantifier. When the quantified object immediately follows the quantifier the genitive clitic is usually omitted, as in (14b).

a. (Do) domandi su mi hi ostal of question:GEN.PL AUX.3PL me.DAT they:GEN remain:PTCP.PL čuda.

much

'Many questions remained me.' (lit. “Of the questions many remained me.”)

b. Su mi ostal čuda domandi.

AUX.3PL me remain:PTCP.PL much question:GEN.PL

'Many questions remained me.'

\subsection{The Molise Slavic particle na/ne}

Molise Slavic has a particle na (ne in Montemitro) which in its very form resembles the Italian partitive particle ne, especially if we take into consideration that

25 For this word order see also the following examples from the Molise Slavic translation of Antoine de Saint-Exupéry's Le Petit Prince (Breu \& Gliosca 2009), with the genitive pronoun referring to quantities (including numbers): si baobaba jesu hi čuda 'if there are many baobabs'; Čeljade? Jesu hi, ja verjam, šest o sedam 'People? There are some, I think, six or seven'. 
akanye (in Acquaviva and San Felice) transforms unstressed $-e$ into $-a$. Both appear in partitive existentials. There is, however, a clear syntactic difference between these particles in the two languages, as Molise Slavic na/ne is always accompanied by the genitive pronoun in partitive function, which, in its turn, was claimed above to be the functional equivalent of the Italian partitive particle ne. In addition - unlike the ordinary existential partitive with Italian ne in the preceding examples - Molise Slavic constructions with $\mathrm{na} / \mathrm{ne}$ as in (15) are very expressive and refer to an unexpectedly large quantity.
(15)
Vogošte ga na JE sira.
this.year he:GEN PTL be:PRS.3SG cheese:GEN.SG.M
Italian: Quest'anno ce n'È di formaggio.
'This year there IS (unexpectedly much) cheese.'

In terms of agreement, it is worth noting that $n a / n e$ combines with the genitive of the noun, whereas the nominative is used when $n a / n e$ is absent and there is no quantifier either, as in (15') Vogošte sir (NOM.SG.M) ga je 'This year there is cheese'. In addition, the existential verb is heavily stressed, symbolized by capitals in (15). In Italian, the existential locative particle ci (ce) is present in such expressive sentences, too. So there is by no means a clear one-to-one correspondence of Italian ne with Molise Slavic na/ne in terms of function and usage.

With an explicit quantifier like čuda 'much' in (16), stress is transferred from the existential verb to the quantifier. Most native speakers accept the addition of the preposition do 'from, of' to the noun as an optional variant, formally corresponding to $d i$ in the Italian translation. In this case do governs the genitive of the noun with an ablativic partitive reading of the prepositional phrase.

$\begin{array}{llll}\text { (Do) sira } & \text { ga } & \text { na je } & \text { ČUDA. } \\ \text { of cheese:GEN.SG.M he:GEN } & \text { PTL be:PRS.3SG much. }\end{array}$

Italian: Di formaggio ce n'è MOLTO.

'There is MUCH cheese.'

With feminine nouns the homonymy of the genitive pronoun and the auxiliary in the form je is somewhat puzzling. But considering the structure of the masculine construction, it is obvious also in sentences like (17) that it is the pronoun je that precedes the particle $n a$, while the auxiliary je follows it. 

(17) Vode
je
na je
ČUDA.
water:GEN.SG.F she:GEN PTL be:PRS.3SG much
Italian: Di acqua ce n'è MOLTA.
'There is MUCH water.'

As na/ne always refers to an unexpectedly large quantity, adding čuda 'much, many' to partitive existentials containing this particle is semantically redundant. This adverb only doubles explicitly what is already implied by na/ne. On the other hand, na/ne could be said to govern the genitive just like quantitative adverbials such as čuda 'much, many', but also na mala 'a little'. An alternative hypothesis will be presented below.

Word order seems to have a role in the case assignment to the noun expressing partitivity in the na/ne construction. In normal word order, i. e., when the noun follows the verb as in (15), the genitive seems obligatory. When it is moved to the front of the sentence as in (16), but with do (also governing the genitive) omitted as in (17), however, the nominative is possible, too. But - as it seems - there is a syntactic break, often signalized by intonation or a little pause, for example, in (17') Voda, je na je (čuda)! 'Water, there is (unexpectedly) much of it!'. Of course, the noun in the examples (15)-(17) may again be completely omitted, if it is clear from the wider context what the speaker has in mind: (17’) Je na je (čuda)! 'There is (unexpectedly) much of it!'.

In the plural, the number of the existential verb in a quantified partitive existential of the na/ne-type depends on the case of the quantified noun. If the noun is in the nominative, it has subject function, and the verb agrees with it in the plural (18a). If it is in the genitive, the verb is in the singular, governed by $n a / n e$ and the quantifier čuda 'much', if it is present (18b). For the sake of comparison, in (18c) the corresponding partitive existential without $n a / n e$ is added, with the above-mentioned change of position of the genitive clitic pronoun to the slot preceding the quantifier čuda.

a. Pumodora hi na jesu (čuda)!

tomato:NOM.PL they:GEN PTL be:3PL much

'There are (unexpectedly) many tomatoes!'

b. Pumodori hi na je (čuda)!

tomato:GEN.PL they:GEN PTL be:3SG much

'There are (unexpectedly) many tomatoes!'

c. Pumodora jesu hi čuda.

tomato:NOM.PL be:3PL they:GEN much

'There are many tomatoes!' 
Note that native speakers readily accept $n a / n e$ in elicitation tests, but this particle is only very rarely found in original examples. If this is true for partitive existential constructions, ${ }^{26}$ it is even more evident for statements containing an object, to which $n a / n e$ refers. Up to now, we have not found a single occurrence in original texts of this type. One example from the elicitation tests of native speakers' acceptance of na/ne is (19), again with the connotation of unexpectedly large quantity.

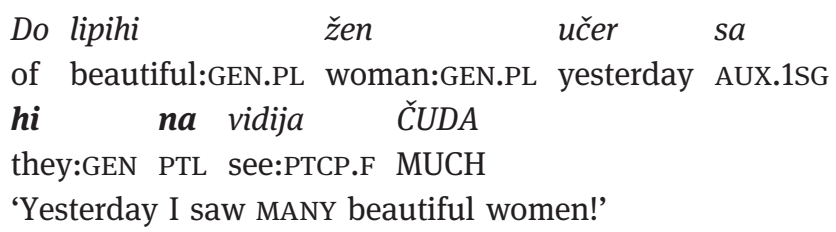

Another example of this type is (20). ${ }^{27}$
(20) Je
$m u$
hi
ne/na vazeja
pet!
AUX.3SG him:DAT they:GEN PTL take:PTCP.SG.M five.
'He took five of them (books) (for) him!'

Whatever the reason for the restriction of the particle na/ne to quantitatively marked statements, the very origin of this puzzling particle is still unclear, too. At first glance, considering akanye, it could be regarded simply as borrowed from Italian ne. Given the fact that akanye is present only in the two dialects of

26 There are two such examples in the romance Andrea Veneziano by Nicola Gliosca with the typical combination of the genitive pronoun and the particle $n a$ immediately preceding the existential verb (here in the imperfect): (1) Utra one vlasa ga na biša čuda do arsenika! 'In these hairs there was (unexpectedly) much [of] arsenic!' (2) Ona numaša brojit fina nonda, korko hi na bihu čuda! 'She could not count until there (= them all), there were so (unexpectedly) many of them!'.

27 This example is from the talk on "Clitic placement in Molisean Croatian" (Molise Slavic) given by Milena Krstić and Silvia Luraghi in Split at the 2013 SLE meeting (their example 17). I added an exclamation mark, in order to render the connotation of an unexpectedly high number, and replaced 'of it' by 'of them' in the English translation, as the literal equivalent of $h i$. Furthermore, 'she' was replaced by 'he', as vazeja 'taken' is the masculine $L$-participle (for forming the perfect), corresponding to feminine vazela, used in Krstić and Luraghi's example (23) Se mu hi vazela pet. This sentence should be translated as 'I took five of them for him', corresponding to their example (17) but without $n a / n e$. My thanks go to Silvia Luraghi for providing me with a PDF version of this PowerPoint presentation, in which the authors speculate that $n a / n e$ may be a "a new clitic in Molisean Croatian", which, irrespective of its special function, actually seems to be the case. 
Acquaviva and San Felice, not in Montemitro, the latter dialect should give us a clue for determining the origin of the form na. As was already mentioned, the dialect of Montemitro has ne, a form perfectly corresponding to Italian ne, e. g., je ne je čuda [she.GEN PTL be.3SG much] 'there is much of it!', je ne je [she.GEN PTL be.3SG] (vode) 'there is (water.GEN)!', ga ne je [he.GEN PTL be.3SG] (sira) 'there is (cheese.GEN)!', always with the connotation of an unexpectedly large quantity. So, these data could support the claim of $n a / n e$ being a loan particle. But Montemitro actually has the form na, too, as a variant of ne, i. e., je na je vode [she.GEN PTL be.3SG water.GEN] and so on, a form that cannot be derived from Italian ne in a dialect without akanye. We will discuss this problem in more detail below in 4.3.

Although genitive pronouns correspond to the Italian partitive marker ne functionally, even for them, apart from the fact that they are optional in many cases in which Italian ne is used obligatorily, there are restrictions in anaphoric contexts. So, in (21), the accusative pronoun $j u$ is used and not the genitive je, but as it seems, only when hoš 'you want' is stressed. Otherwise it is omitted. In Italian, either the partitive particle ne is present, corresponding to $\varnothing$ in Molise Slavic, or (with the stress on vuoi 'you want') the accusative pronoun la, corresponding exactly to Molise Slavic ju. So in the diagrammar we have the correspondences $\emptyset:$ ne and $j u$ : la. Of course, Molise Slavic na/ne is completely excluded, as "large quantity" does not play any role here.

(21) Jimam čuda magini, Ø hoš jenu? ( ...ju HOŠ jenu)

Italian: Ho molte macchine, ne vuoi una? ( ... la VUOI una)

'I have many cars, do you want one of them?'

When the object in the interrogative clause is omitted, as in (22), stress always falls on the verb. In this case both structures are possible, i. e., $\varnothing \sim j u$ in Molise Slavic and ne $\sim a$ in Italian, with the same correspondences in the diagrammar as in (21). ${ }^{28}$

(22) Jimam vodu, Ø HOŠ? ( ju)

Italian: Ho acqua, ne VUOI? ( la)

'I have water, do you want some?'

28 Unlike in (21), in (22) an explicitly anaphoric reading '... do you want it', instead of the partitive one, would not be excluded in either language if the pronoun $(j u: l a)$ were present. 


\section{Some special problems in Molise Slavic partitives and possible solutions}

\subsection{The genitive puzzle}

As stated above in paragraph 2, the genitive is not possible for nouns expressing partitivity in object position, and, as was shown in 3.2, it is also excluded in existential constructions (with or without a genitive pronoun). The only possibility for partitive genitives mentioned up to now was in combination with quantitative adverbials and/or the particle na/ne. There are, however, also examples for a genitive outside such constructions, as in (23a)-(23b).
a. Ja sa
pija,
VODE!
I AUX.1SG drink:PTCP.SG.M water:GEN.SG.F
'I drank... water!'
b. JE
robe!
be:PRS.3SG stuff:GEN.SG.F
'There is (a lot of) stuff!'

In (23a) the genitive noun vode is heavily stressed and signalizes an object that is meant to be a surprise. It is separated from the verb by a pause, unlike an ordinary object in the accusative, which expresses bare partitivity, among other things, as in Ja sa pija vodu 'I drank (some) water'. In the existential construction (23b) stress is on the existential verb je, and the genitive noun alone expresses an "unexpectedly large quantity". No wonder that (23b) could easily be extended by $n a / n e$ together with its obligatorily preceding genitive pronoun to (23b') Je na JE robe, without any noticeable difference in meaning. In Italian, however, the particle ne would be a necessary component in a sentence corresponding to (23b), i. e., marking partitivity is compulsory here. So (23b) could only be translated as ce n'E di roba! Obviously, this difference has to do with the semantic distinction between the highly marked $n a / n e$ in Molise Slavic and the neutral partitive in Italian.

What could be absent in the Italian translation of (23b) is the preposition $d i$ 'of' (ce n'E roba), by which the formal parallelism with the Molise Slavic genitive would be lost, without any noticeable change of meaning. In an Italian translation of (23a), Ho bevuto, ACQUA!, the preposition di before acqua is even completely impossible, in spite of the genitive vode in Molise Slavic. So the equivalence between Italian and Molise Slavic seems rather restricted in this case. The reason for these differences, which are not due to any type of Slavic 
conservatism, as the genitive traditionally does not express a large quantity, is still unclear. To resolve this problem, specific research would first need to be carried out in Italian dialect syntax.

As for Molise Slavic, it could well be that the basic marker for "unexpectedly large quantity" in existentials is the stress on the verb combined with the genitive. If this is right, the genitive in the Molise Slavic na/ne constructions originally was not governed by the particle as a marker of "unexpectedly large quantity"; on the contrary, na/ne (with its preceding partitive pronoun) was just an optional element that could be identified with the Italian particle ne, irrespective of its own etymology (see 4.3 below). This is an alternative hypothesis to the assumption that na/ne could be treated as a quantifier like čuda 'much', presented above. It is, however, an open question why the parallel usage of Italian ne and Molise Slavic na/ne remained restricted to this function in particular, leaving open many cases of partitivity in which na/ne in Molise Slavic is excluded, while ne in Italian is perfectly possible or even obligatory. Given the total absence of $n a / n e$ in older texts, we might only speculate about a more similar usage in the past with a language-internal specialization later on.

To sum up, na/ne by no means corresponds directly to Italian ne, in spite of their formal resemblance. The real equivalents of Italian ne are the Molise Slavic genitive pronouns, with or without a following na/ne. An independent argument for this assumption emerges from the idiomatic expression si ga pokj [REFL.DAT it.GEN go.PFV.INF] 'to leave', si ga grem [REFL.DAT it.GEN go.IPFV.PRS.1SG] 'I leave' and so on. Here, the masculine and neuter genitive pronoun ga in fact corresponds exactly to the partitive particle ne in the Italian equivalents andarsene, ${ }^{29}$ me ne vado.

\subsection{The perfect puzzle}

In the present perfect the order of clitics somehow changes in (partitive) existential constructions. The situation is rather complex as it involves, among other things, the polysemic form je, expressing existentiality and partitivity and serving as a perfect auxiliary, as well as cases of haplology.

29 In standard Italian, the reflexive particles se and ne follow the bare infinitive. In modal constructions the position corresponding to the Molise Slavic order also exists, i. e., devo andarmene = me ne devo andare 'I must leave', preferred in southern Italian dialects (Rohlfs 1968: 173-174), which are the predominant model for Molise Slavic; see Breu (2019: 417-420) for a discussion. The phrasal verb andarsene is one case in which the original locative meaning of the partitive particle ne (< Latin inde 'from there') still shines through. 
While the genitive pronoun precedes the inflected verb in the (synthetic) present and imperfect tenses, it follows it in the analytic perfect. So the existential sir ga je [cheese he.GEN be.PRS.3SG] 'there is some cheese', sir ga biša [cheese he. GEN be.IPRF.3SG] 'there was some cheese' becomes sir je ga bija [cheese AUX.3SG he.GEN be.PTCP.M] 'there has been some cheese'. This change of position holds for the whole complex of the $n a / n e$ construction with the partitive personal pronoun, too. So, for example, sira ga na je! [cheese he.M PTL be.PRS.3SG] 'there is (an unexpectedly large quantity of) cheese!' becomes sira je ga na bija [cheese AUX.3SG he.GEN PTL be.PTCP.M] 'there has been (an unexpectedly large quantity of) cheese'. But we have to remember that je 'is' has two different functions here. While it is an existential verb in the present, it is an auxiliary in the perfect. This means that what follows the genitive pronoun is the existential verb je, and what precedes it is je as an auxiliary. The same homonymy exists in the plural with, for example, jaja hi jesu [eggs they.GEN be.3PL] 'there are some eggs' (present: jesu = existential), but jaja jesu hi bil [eggs AUX.3PL they.GEN be.PTCP.PL] 'there have been some eggs' (perfect: jesu = auxiliary).

In Italian, there is no such change of position: uova ce ne sono 'there are some eggs' vs. uova ce ne sono state 'there have been some eggs'. The reason for this difference is that in Italian the partitive particle, like all other clitics, precedes the inflected verb in declarative sentences, including the auxiliaries, whereas in Molise Slavic (with the only exception being the negative marker ne) clitics precede the (semantically) full verb, even if it is a participle as in the case of the perfect.

In negative existentials like sir ga nija-ga [cheese he.GEN NEG.AUX.3SG-he. GEN] 'there is no cheese' with the (optional) partitive pronoun following the noun and preceding the negated verb, with its concomitant genitive pronoun, the perfect allows only for one ga, i. e., sir nija-ga bija < ${ }^{*}$ sir nija-ga ga bija [cheese NEG.AUX.3SG-he.GEN he.GEN be.PTCP.M]. This is a case of haplology, cancelling out the difference between a pure and a partitive existential.

There is a similar problem in the affirmative perfect, too, though restricted to feminines. Here from the ungrammatical *voda je je bila [water AUX.3SG she.GEN be.PTCP.F] 'there has been (some) water', we get the perfect voda je bila with only one je, and likewise with the particle na: voda je na bila! 'there was (an unexpectedly large quantity of) water!'. Obviously the form je stands here for both the personal pronoun and the auxiliary preceding it.

In the present tense, another case of haplology excludes the doubling of the form je in *voda je je [water she.GEN be.3SG]. Again only one je is possible, i. e., voda je 'there is (some) water', with je representing in this case both the feminine genitive pronoun and the homophonous existential verb. These cases show that cancelling out by haplology is not restricted to double forms with the 
same function (partitive genitive pronoun) but affects different parts of speech (auxiliary or existential verb and genitive pronoun), too. In the feminine perfect of the negative existential construction, haplology works, of course, in the same way as with the masculines, cf. voda je nija-je [water she.GEN NEG.AUX.3SG-she. GEN] 'there is no water' in the present, but voda nija-je bila < ${ }^{*}$ voda nija-je je bila [water NEG.AUX.3SG-she.GEN she.GEN be.PTCP.F] 'there has not been (any) water' in the perfect.

We find one more case of haplology in another area of grammar, showing that it is not even restricted to the domain of the genitive pronouns. I am referring to the clash of feminine dative and accusative clitic pronouns. While there is no problem for masculines with their different forms mu DAT and ga ACC, as in ja sa mu ga $d a$ [I AUX.1SG he.DAT he.ACC give.PTCP.M] 'I have given him to him', the homonymy in the feminine pronoun $j u$ DAT =ACC again leads to haplology, resulting in ja sa ju da 'I have given her to her' < *ja sa ju ju da [I AUX.1SG she.DAT she.ACC give.PTCP.M] as the only possible form.

\subsection{The na/ne puzzle}

Apart from the fact that $n a / n e$, unlike Italian ne ( $\left.n^{\prime}\right)$, has a strong connotation of an unexpectedly large quantity, bilingual speakers are puzzled by the asymmetry in existential partitives when discussing constructions like (24). ${ }^{30}$ Obviously, the Italian partitive particle ne has two correspondences in Molise Slavic, the personal pronoun in the genitive je and the particle $n a / n e$. On the other hand, the Italian locative existential particle $c i\left(c e, c^{\prime}\right)$ has none, when expressing the existence of a referent in combination with the existential verb bit 'to be'. The Italian construction is equivalent to čə nə šta d'acquə in local colloquial Italian, so the asymmetry compared with Molise Slavic remains the same.

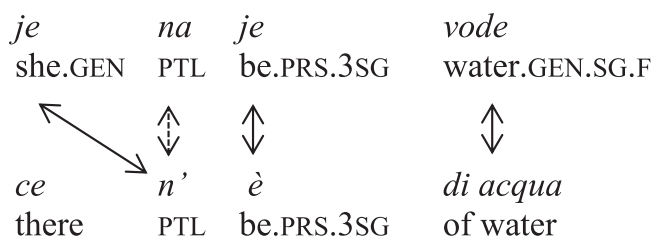

As mentioned above, the origin of Molise Slavic na/ne is by no means clear, in spite of its superficial similarity to the Italian partitive particle, due to problems

30 For the sake of simplicity in this and the following schemes na represents both variants $n a$ and $n e$. 
of form and usage, but especially also because of its expressive connotation. The only real functional equivalent of Italian ne is the genitive pronoun in Molise Slavic. This situation is marked in (25) by glossing the Molise Slavic particle with a question mark.

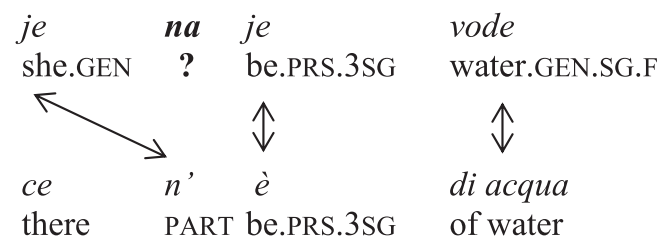

In the following we will discuss some possible solutions for the origin of the particle na/ne, but only with respect to its form. As for its connotation of "unexpectedly large quantity", we have ascribed this to the genitive of the noun it refers to. It could then have passed secondarily to $\mathrm{na} / \mathrm{ne}$, retaining it in the absence of a genitive noun, too.

The first hypothesis is based on the homonymy of the locative particle $c i$ in Italian existential phrases with the dative plural $c i$ of the personal pronoun noi 'we'. So, it could have been identified with this form and rendered with its equivalent in Molise Slavic, which is nami (us.DAT), ${ }^{31}$ possibly shortened to na as a clitic in this special function. In synchronic terms this type of pattern borrowing would result in the diagrammatic structure (26), with the word order of clitics remaining the only difference between the two languages in absolute language contact.

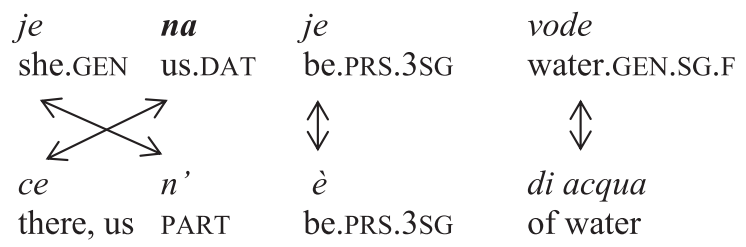

This hypothesis must, however, be rejected due to the existence of the nonakanye form ne in the dialect of Montemitro, which by no means can be derived from nami.

31 Interestingly, in southern Italian dialects the dative plural form of the pronoun 'we' may be derived from inde 'from where' (Rohlfs 1968: 158-159), which is also the etymology of the Italian partitive particle ne (see above). So there is some connection between $\mathrm{ci}$ and ne also on independent grounds. 
Therefore, the second hypothesis comes into play, namely the aforementioned possibility of borrowing the particle ne directly from Italian, i. e., matter loan. In this case ne (or its akanye form na) would have been added to the existing genitive pronoun for expressing partitivity, with the result of a double expression of partitivity in Molise Slavic and the interpretation of Italian $\mathrm{ci}$ as doubling the existential function of bit 'to be', as represented in (27).

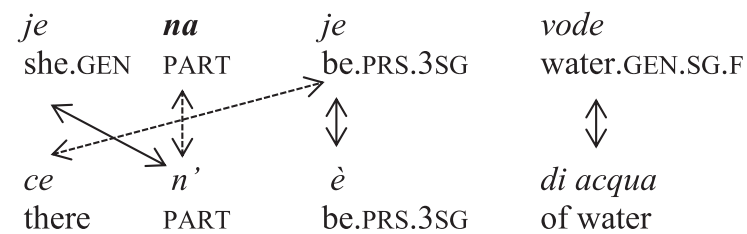

But this hypothesis once again results in a pseudo-solution, because na is a possible form in Montemitro, too. As na cannot be derived from ne phonetically in a non-akanye dialect, matter borrowing from Italian should be excluded. ${ }^{32}$

A third solution comes from the locative characteristics of the Italian existential particle $c i$. Here, na could go back to a locative particle in Molise Slavic, specifically the local adverb nonda 'there' in Acquaviva, shortened to na in the clitic position, or nonde in Montemitro, shortened to ne. This case of pattern borrowing would result in a structure like (28) in the diagrammar of the bilingual speakers, superficially resembling (26) and again with a clear one-to-one relation between the partitive and the existential elements of both languages in contact, though with the opposite word order.

\begin{tabular}{|c|c|c|c|}
\hline $\begin{array}{l}\text { je } \\
\text { she.GEN }\end{array}$ & $\begin{array}{l}\boldsymbol{n a} \\
\text { PART }\end{array}$ & $\begin{array}{l}\text { je } \\
\text { be.PRS.3SG }\end{array}$ & $\begin{array}{l}\text { vode } \\
\text { water.GEN.SG.F }\end{array}$ \\
\hline & & $\downarrow$ & $\S$ \\
\hline $\begin{array}{l}c e \\
\text { there }\end{array}$ & $\begin{array}{l}n \\
\text { PART }\end{array}$ & $\begin{array}{l}\grave{e} \\
\text { be.PRS.3SG }\end{array}$ & $\begin{array}{l}\text { di acqua } \\
\text { of water }\end{array}$ \\
\hline
\end{tabular}

While this solution could explain the alternation between the akanye form na in Acquaviva and the non-akanye form ne in Montemitro, it is just as unable as the hypothesis of borrowing from Italian to explain the alternative form $n a$ in the Montemitro dialect.

32 As a matter of fact, we cannot completely exclude an irregular vowel change in such a highly grammaticalized element, allowing for both variants in Montemitro. But as this would be an isolated case, it seems highly improbable, in spite of the absence of stress on na/ne. 
There is a fourth hypothesis, managing without the necessity of compressing a local adverb by associating Italian ne with the genuine Slavic interjection $n a$, originally used when presenting or giving something to another person, e. g., na (ti) ovo 'here [is] this (for you SG)', literally "here (you DAT.SG) this". ${ }^{33}$ The resulting structure in the diasystem would be of the same type as (28). But, once again, the Montemitro dialect creates problems, as such a solution does not explain its opposite variant ne. In addition, the interjection is always stressed in its original function, while $n a$ in the partitive constructions is not. ${ }^{34}$

Summing up, na in the Acquaviva (and San Felice) dialect could be explained by all four hypotheses presented so far, ranging from direct borrowing of the Italian partitive particle ne (by means of akanye) to semantic calquing of the polysemy of the Italian form ci, functioning as the dative of the pronoun 'we' and as a locative existential particle, and the functional expansion of a Molise Slavic local adverb or interjection. But each "solution" proves unable to explain one of the two variants in the Montemitro dialect, i. e., ne or na. So, it seems that none of the monocausal hypotheses is justified and we have to fall back on a bior pluricausal explanation, combining a solution explaining ne (borrowing of Italian ne or reduction of the locative adverb nonde) with another explaining na (reduction of nami, the dative of the personal pronoun mi 'we', or functional expansion of the interjection $n a$ ) in the dialect of Montemitro.

There is, however, also a fifth hypothesis that could explain all forms of $n a /$ $n e$ in the three dialects by replacing the assumption of standard Italian ne as the borrowed source form by a dialectal alternative, namely nə, showing an unstressed schwa in the critical position. Such a schwa would, of course, turn into an - $a$ in Acquaviva and San Felice. The question is how schwas of the source are rendered in Montemitro, i. e., whether they have both results, $-e$ and $-a$, leading to the desired forms ne and na. The answer, however, is not easy. Romance schwa in final syllables is substituted in Molise Slavic with the endings of the respective inflectional classes, as far as the inflected parts of speech are concerned, including adverbs, absorbed by the neuter gender. Other parts of speech mostly do not show the necessary structure with a final schwa. An exception is the complementizer cha 'that' (Giammarco 1968-1979: 515; Italian che), adopted as $k a$ in Acquaviva and San Felice but exclusively as $k e$ in Montemitro, i.e., just like a standard Italian $-e$, which would exclude an

33 It also has an inflected plural form, as in nata 2PL na mala kruha "here is some bread for you PL'; literally: "here 2PL a little bread".

34 The high degree of homonymy in the forms na and ne would offer even more (though highly improbable) etymologies for this particle, involving the Molise Slavic preposition na 'on', the indefinite article $n a$ and the negative particle $n e$. 
integration of dialectal nə as na. As for unstressed schwas in word-internal position, there is at least one example of its integration as - $a$ in Montemitro, namely in the adverb sakreto 'secretly' (Italian in segreto, Acquaviva zakrata) $\leftarrow$ dial. n-zacrétə 'secretly', sacrétə 'secret' (Giammarco 1968-1979: 1979-1980).

So, considering both types of integration of foreign $a$ in the Montemitro dialect, for example $k \boldsymbol{\partial} \rightarrow \boldsymbol{k} \boldsymbol{e}$ and sacretə $\rightarrow$ sacreto, there could, indeed, exist a variation for the integration of Romance schwa, which could eventually explain also the two variants ne and na of one single word. Up to now, no parallel cases have been found. So, this monocausal hypothesis on the basis of borrowing dialectal no is still on rather shaky foundations, the more so as the form sakreto could have been contaminated with the traditional Slavic verb sakrit 'to hide', preserved in the Montemitro variety. Obviously, more detailed research into the borrowing from Romance dialectal sources in the dialect of Montemitro is required in order to validate this hypothesis.

From a functional point of view, we have to consider once again the fact that na/ne in Molise Slavic is much less frequent than ne in Italian and even excluded in all non-exclamatory situations. So, it is by no means a simple partitive particle. On the other hand, it cannot appear in bare existential sentences either, which excludes functional identification with the Italian locative existential particle $c i$, despite the fact that both Italian ne and $c i$ have locative etymologies.

\section{Conclusion}

Unlike many Slavic languages, Molise Slavic has neither a partitive case nor a partitive genitive of nouns, i. e., direct objects remain in the accusative, even if only part of the referents in question is affected by the action of the verb. This is also true for negative statements and irrespective of verbal aspect. So, this minority language in total language contact with Italian and its local varieties is very different in this respect compared with Russian but also with its "genetically" nearest standard language, Croatian. Language contact with caseless Italian could have been one of the reasons for the loss of this differentiation.

The only role of the genitive in the domain of partitivity is its function of expressing surprise and unexpectedly large quantities. Apart from this, the genitive continues to be governed by adverbial quantifiers, but also by the innovative partitive particle ne/na. In addition it is governed by the preposition do 'of, from', with which the ablativic partitive is formed, and which corresponds to Italian di in prepositional phrases with this function. 
As this paper has shown, partitivity is also expressed by other grammatical means, especially with regard to pronouns and particles. Taking simple existentials as a starting point, this research concentrated on partitive existentials, formed with the help of the partitive particle ne in Italian, added to existentials. In many cases, clitic genitive personal pronouns turned out to be the exact Molise Slavic equivalent of the Italian partitive particle, including even the case of the phrasal verb si ga pokj 'to leave', corresponding to Italian andarsene, in which the particle ne has preserved its originally locative meaning. As shown above, there are several haplologies of the partitive pronoun with verb forms that lead to a formal coincidence of partitive existentials with bare existentials.

There are, however, complications in connection with the Molise Slavic innovative particle na, which resembles the Italian partitive particle with respect to its form but not its expressive connotation. Several hypotheses were tested to explain its emergence in Molise Slavic, but all of them led to phonetic problems with respect to the variation of na with ne in the nonakanye dialect of Montemitro. Apart from pluricausal explanations, this problem could best be resolved by the hypothesis based on matter borrowing from an Italian dialectal source no, corresponding to standard Italian ne with similar functions. This solution faces the problem, however, that na/ne did not simply replace the genitive pronouns in their partitive function, but made them precede it as an obligatory companion. Furthermore, its expressive connotation is alien to Italian ne. Finally, there is a typological problem for the hypothesis of matter borrowing in the fact that the new particle has been integrated firmly into the domain of clitics, normally as inaccessible to borrowings as inflectional endings.

\section{References}

Bentley, Delia, Francesco Maria Ciconte \& Silvio Cruschina. 2013. Existential constructions in crosslinguistic perspective. Italian Journal of Linguistics (Rivista Di Linguistica) 25.1, 1-13.

Breu, Walter. 1994. Der Faktor Sprachkontakt in einer dynamischen Typologie des Slavischen. In Hans Robert Mehlig (ed.), Slavistische Linguistik 1993, 41-64. Munich: Otto Sagner.

Breu, Walter. 2003. Bilingualism and linguistic interference in the Slavic-Romance contact area of Molise (Southern Italy). In Regine Eckardt, Klaus von Heusinger \& Christoph Schwarze (eds.), Words in time (Trends in linguistics. Studies and monographs 143), 351-373. Berlin \& New York: Mouton de Gruyter.

Breu, Walter. 2012. The grammaticalization of an indefinite article in Slavic micro-languages. In Björn Wiemer, Björn Hansen \& Bernhard Wälchli (eds.), Grammatical replication and 
borrowability in language contact (Trends in linguistics: Studies and monographs 242), 275-322. Berlin \& Boston: De Gruyter Mouton.

Breu, Walter. 2013. Zahlen im totalen Sprachkontakt: Das komplexe System der Numeralia im Moliseslavischen. In Tilmann Reuther (ed.), Slavistische Linguistik 2012. (Wiener Slawistischer Almanach 72), 7-34. Munich: Otto Sagner.

Breu, Walter. 2017. Slavische Mikrosprachen im absoluten Sprachkontakt. Band I. Moliseslavische Texte aus Acquaviva Collecroce, Montemitro und San Felice del Molise. Glossierte und interpretierte Sprachaufnahmen aus Italien, Deutschland, Österreich und Griechenland (Slavistische Beiträge 505). Wiesbaden: Harrassowitz.

Breu, Walter. 2019. Morphosyntactic change in Slavic micro-languages: The case of Molise Slavic. In Andrii Danylenko \& Motoki Nomachi (eds.), Slavic on the language map of Europe (Trends in linguistics 333). Berlin \& Boston: De Gruyter Mouton.

Breu, Walter \& Giovanni Piccoli. 2012. Südslavisch unter romanischem Dach: Die Moliseslaven in Geschichte und Gegenwart im Spiegel ihrer Sprache, Teil II: Texte gesprochener Sprache aus Montemitro und San Felice del Molise (Sagners Slavistische Sammlung 32/2). Munich: Otto Sagner.

Breu, Walter \& Nicola Gliosca. 2009. Antoine de Saint Exypéry, Le Petit Prince (Mali Kraljič. Tradučan na-našu jiz frančezoga do Walter Breu aš Nicola Gliosca) [The Little Prince. Translated into Molise Slavic by Walter Breu and Nicola Gliosca]. Neckarsteinach: Tintenfaß.

Daniel, Michael. 2014. The second genitive in Russian. In Silvia Luraghi \& Tuomas Huumo (eds.), Partitive cases and related categories (Empirical approaches to language typology 54), 347-378. Berlin \& Boston: De Gruyter Mouton.

de Hoop, Helen. 2003. Partitivity. In Lisa Cheng \& Rint Sybesma (eds.), The second glot international state-of-the-article book: The latest in linguistics, 179-212. Berlin \& New York: Mouton de Gruyter.

Giammarco, Ernesto. 1968-1979. Dizionario Abruzzese e Molisano. 4 parts. Rome: Edizioni dell'Ateneo \& Bizarri.

Koptjevskaja-Tamm, Maria. 2001. “A piece of the cake” and "a cup of tea”: Partitive and pseudo-partitive nominal constructions in the Circum-Baltic languages. In Östen Dahl \& Maria Koptjevskaja-Tamm (eds.), Circum-Baltic languages: Grammar and typology, 523-568. Amsterdam \& Philadelphia: John Benjamins.

Luraghi, Silvia \& Seppo Kittilä. 2014. Typology and diachrony of partitive case markers. In Silvia Luraghi \& Tuomas Huumo (eds.), Partitive cases and related categories (Empirical approaches to language typology 54), 17-62. Berlin \& Boston: De Gruyter Mouton.

Paykin, Katia. 2014. The Russian partitive and verbal aspect. In Silvia Luraghi \& Tuomas Huumo (eds.), Partitive cases and related categories (Empirical approaches to language typology 54), 379-398. Berlin \& Boston: De Gruyter Mouton.

Raguž, Dragutin. 1997. Praktična hrvatska gramatika [Practical Croatian grammar]. Zagreb: Medicinska naklada.

Rešetar, Milan. 1911. Die serbokroatischen Kolonien Süditaliens. Vienna: Kaiserliche Akademie der Wissenschaften.

Rohlfs, Gerhard. 1968. Grammatica storica della lingua italiana e dei suoi dialetti. Morfologia. Turin: Einaudi.

Rohlfs, Gerhard. 1969. Grammatica storica della lingua italiana e dei suoi dialetti. Sintassi. Turin: Einaudi. 
Seržant, Ilja A. 2014. The independent partitive genitive in North Russian. In Ilja A. Seržant \&

Björn Wiemer (eds.), Contemporary approaches to dialectology: The area of North,

Northwest Russian and Belarusian dialects (Slavica Bergensia 13), 271-329. Bergen:

Department of Foreign Languages, University of Bergen.

van Coetsem, Frans. 2000. A general and unified theory of the transmission process in

language contact. Heidelberg: Winter.

Weinreich, Uriel. 1954. Is a structural dialectology possible? Word 10(2-3). 388-400.

Weinreich, Uriel. 1979 [1953]. Languages in contact: Findings and problems. The Hague \& Paris: Mouton. 